\title{
The Effect of Sendai Virus Infection on Bactericidal and Transport Mechanisms of the Murine Lung
}

\author{
George J. Jakab and Gareth M. GreeN \\ From The Respiratory Diseases Research Laboratory, Department of Medicine, \\ University of Vermont College of Medicine, \\ Burlington, Vermont 05401
}

\begin{abstract}
A в S T R A C T Pulmonary virus infections predispose to bacterial infections in the lung. The mechanism of this effect was studied by quantitative comparison of the effects of airborne acute viral infection on pulmonary transport vs. in situ bactericidal mechanisms in mice. Animals infected by aerosol with $10^{4} \mathrm{TCID}_{50}$ of Sendai virus developed pathologic pulmonary changes of interstitial pneumonitis, bronchial epithelial desquamation, and peribronchial mononuclear cell infiltration 7 days later. At that time, the mice were challenged with an aerosol of viable ${ }^{32} \mathrm{P}$-labeled Staphylococcus aureus. Pulmonary bactericidal activity and physical transport by the lung were determined by the determination of viable staphylococcal and ${ }^{32} \mathrm{P}$ radiotracer counts respectively at $4,24,48$, and 72 $\mathrm{hr}$ after bacterial challenge. Infected mice showed a significant decrease from normal in the rate of reduction of viable bacterial counts in the first $4 \mathrm{hr}$ after challenge followed by a proliferation of the staphylococci. By contrast, radiotracer removal rates at 4 and $24 \mathrm{hr}$ were similar in infected and noninfected mice. There was a small but significant retention of ${ }^{32} \mathrm{P}$ in the lungs of the infected animals at the later periods. These data demonstrate that bacterial multiplication associated with virus infection of lungs is related to defects in in situ bactericidal (phagocytic) mechanisms rather than transport mechanisms of the lung, despite histologic evidence of extensive destruction of bronchial-ciliated epithelium.
\end{abstract}

\section{INTRODUCTION}

Virus infection often predisposes to bacterial disease in the lung. The interaction of virus and bacterial agents in respiratory infections in experimental animals has been

This study was presented in part at the 71st Annual Meeting of the American Society for Microbiology in Minneapolis, Minn., 4 May 1971.

Received for publication 14 December 1971 and in revised form 10 February 1972. reviewed recently by Loosli (1). Virus infections enhance the mortality to subsequent bacterial inoculations by impairing normal "clearance" mechanisms of the bronchopulmonary tree (2).

Pulmonary "clearance" of infectious agents is comprised of physical transport and bactericidal mechanisms (3). In the tracheobronchial tree, physical transport is achieved by the mucociliary escalator; the pulmonary parenchyma is cleared by the less well-understood alveolobronchiolar transport system. Bactericidal functions of the lung have been attributed primarily to the phagocytic capacity of alveolar macrophages which clear the lung of infectivity by killing, inactivating, or limiting the growth of infectious organisms (4).

Influenza (2), reo- (5), and Sendai virus (6) infections are known to inhibit pulmonary antibacterial defenses. It is generally held that mucociliary transport activity is an important mechanism of resistance to bacterial infections of the respiratory tract and that viral infections of the respiratory tract impair host resistance to bacterial infection through the lesions of the respiratory epithelium and impairment of mucociliary function. However, viral suppression of host defenses has been attributed to suppression of phagocytic mechanisms in the lung $(2,5)$ and virus infection is known to inhibit the antibacterial activity of phagocytic cells (7).

To date, there is no adequate demonstration in quantitative terms of the comparative effects of moderate to severe virus infections in the lung on the pulmonary bactericidal vs. the transport mechanisms. The present study was designed to elucidate in quantitative terms, the relative effect of Sendai virus infection of the tracheobronchial tree on transport mechanisms of the lung vs. in situ bactericidal mechanisms.

\section{METHODS}

Animals. White male Swiss mice (CBL-HAM/ICR strain) weighing $18-20 \mathrm{~g}$ and showing no serologic evi- 
TABLE I

In Vitro ${ }^{32} P$ Separation from ${ }^{32} P$-Labeled Staphylococcus aureus

\begin{tabular}{|c|c|c|c|}
\hline $\begin{array}{l}\mathrm{Hr} \text { after } \\
\text { labeling }\end{array}$ & $\begin{array}{l}\text { Per cent of } \\
\text { initial } \\
\text { 32 } \mathrm{P} \text { counts }\end{array}$ & \pm & $\mathrm{SE}$ \\
\hline 24 & $99.3^{*}$ & \pm & 2.2 \\
\hline 48 & 91.3 & \pm & 1.7 \\
\hline 72 & 75.6 & \pm & 1.9 \\
\hline
\end{tabular}

* Mean of three separate determinations.

dence of Sendai virus infection were used. Animals were housed in filter-topped plastic cages (Carworth Div., Becton, Dickinson \& Co., New York) and fed Purina Lab Chow (Ralston Purina Co., St. Louis, Mo.) and water ad lib.

Virus. Influenza D/Sendai/52, obtained from the American Type Culture Collection, was harvested in the allantoic fluid of 13-day old chick embryos after incubation at $37^{\circ} \mathrm{C}$ for 2 days, titered in cultures of rhesus monkey kidney tissue cultures and stored at $-70^{\circ} \mathrm{C}$ in small portions; the titer of this stock preparation was $10^{\circ} \mathrm{TCID}_{50} / \mathrm{ml}^{1}{ }^{1}$

Preparation of bacterial aerosol. Staphylococcus aureus (coagulase-positive FDA strain 209P, Phage type 42D) was labeled with ${ }^{32} \mathrm{P}$ by the method of Green and Goldstein (8). In this procedure, the organism was inoculated into $70 \mathrm{ml}$ of a phosphorus-free culture medium containing $1.0 \mathrm{mCi}$ of ${ }^{32} \mathrm{P}$. After $18 \mathrm{hr}$ of growth at $37^{\circ} \mathrm{C}$ in a rotating shaker water bath, the labeled cells were centrifuged, washed twice in $30 \mathrm{ml}$ of phosphate buffer, $\mathrm{pH} 7.4$, to remove all unattached label, and resuspended in $16 \mathrm{ml}$ of the buffer solution.

To determine ${ }^{32} \mathrm{P}$ separation from the bacterium, labeled cultures were washed and resuspended in phosphate buffer every $24 \mathrm{hr}$ for 3 days. Radiotracer activity of these washed cultures was assayed on the final day (Table I).

Animal exposure. A modification of the Henderson aerosol apparatus (9) was constructed to achieve airborne infection of the murine lung. Briefly, the apparatus consisted, in sequence, of a Collison atomizer (10) activated by compressed air, a $6 \times 80 \mathrm{~cm}$ length of Plexiglas tubing to mix the nebulized agent with diluting air, a large Plexiglas cylindrical chamber $(28 \times 60 \mathrm{~cm})$ for 72 individually separated mice, a fiber glass prefilter, two absolute-type bacterial filters, and a vacuum pump.

The atomizer produced a continuous cloud of small infectious liquid droplets in the vented exposure chamber. The particle size distribution of the aerosol was determined with an Andersen air sampler (11). During the 30-min exposure periods, the entire system was kept at a continuous 0.5 inches of vacuum as measured with a water manometer.

Virus concentrations in the animal-holding chamber, sampled with an all-glass impinger (12), were $10^{1.6}$ TCID $_{50} /$ cc of chamber air. Mice were exposed to this infectious atmosphere for $30 \mathrm{~min}$. The minute ventilation of the mouse being $1.24 \mathrm{cc} / \mathrm{min}$ per $\mathrm{g}$ of weight (13), the animals inhaled approximately $10^{4} \mathrm{TCID}_{50}$ of Sendai virus. Extensive previous study of mice infected with this virus has shown that this dose induced pulmonary virus titers of $10^{7}$ TCID $_{50}$ per lung 4 days after virus infection, after which the virus was rapidly eliminated, usually by day $9(14,15)$.

${ }^{1}$ Abbreviation used in this paper: $\mathrm{TCID}_{50}$, tissue culture infective dose median.
Bacteriologic and radioassay procedures. 7 days after infection with Sendai virus, animals were exposed for 30 $\min$ to an aerosol of ${ }^{32} \mathrm{P}$-labeled $S$. aureus. Immediately after staphylococcal challenge $(0 \mathrm{hr})$ and at $4,24,48$, and $72 \mathrm{hr}$ thereafter, groups of six to nine mice were killed by cervical dislocation. Their lungs were aseptically removed by transection of the mainstem bronchi, and were homogenized in $3 \mathrm{ml}$ of trypticase soy broth (TS). $1 \mathrm{ml}$ of the homogenate was diluted appropriately and cultured quantitatively in TS agar in quadruplicate on Petri X-plates (Falcon Plastics, Div. of BioQuest, Oxnard, Calif.).

Quantitative measurement of ${ }^{32} \mathrm{P}$ activity of the lungs was performed on $1 \mathrm{ml}$-portions of each lung homogenate. The samples were prepared for liquid scintillation counting by digestion in $2 \mathrm{ml}$ of hyamine of hydroxide $10 \times$ overnight at room temperature in $20-\mathrm{ml}$ screw cap glass counting vials. After digestion, $5 \mathrm{ml}$ of absolute ethanol and $10 \mathrm{ml}$ of liquid scintillation solution containing $0.5 \% \mathrm{PPO}$ (2, 5-diphenyloxazole) and $0.01 \%$ POPOP (1,4-bis[2-(5phenyloxazolyl]-benzene) dissolved in toluene were added to each vial. The samples were assayed in a Beckman liquid scintillation spectrometer (LS-150 series, Beckman Instruments, Inc., Fullerton, Calif). After correction for dilution, quench, and background, radioactivity was expressed as counts/minute per milliliter of lung homogenate assayed.

Calculation of pulmonary bactericidal activity. Pulmonary bactericidal activity defined as the change in the proportion of viable to total bacteria in the lung was calculated in each individual animal by the radioactive ratio method of Green and Goldstein (8). The ratio of bacterial to radioactive counts was determined for the organism in the aerosol and in the lungs. Bactericidal activity was calculated from the change that occurred between the two ratios and is expressed as a percentage of the ratio in the aerosol as follows:

\section{Per cent bacteria remaining}

$$
\begin{aligned}
& =\frac{\left(\text { Bact. count } /{ }^{32} \mathrm{P} \text { count }\right)}{(\text { lung }) \times 100} \\
& =\frac{\text { Ratio (lung) } \times 100}{\text { Ratio (aerosol) }}
\end{aligned}
$$

TABLE II

Particle Size Distribution of ${ }^{32} P$-Labeled Staphylococcus aureus

\begin{tabular}{|c|c|c|c|}
\hline \multirow[b]{2}{*}{$\begin{array}{l}\text { Andersen } \\
\text { sampler } \\
\text { stage }\end{array}$} & \multirow[b]{2}{*}{$\begin{array}{l}\text { Aerodynamic } \\
\text { size* }\end{array}$} & \multicolumn{2}{|c|}{ Per cent of total } \\
\hline & & $\begin{array}{c}\text { Viable } \\
\text { staphylococci } \\
\text { recovered } \pm S E\end{array}$ & $\begin{array}{l}\text { \$2 } \mathrm{P} \text { counts } \\
\text { recovered } \pm \mathrm{SE}\end{array}$ \\
\hline & $u$ & & \\
\hline 1 & $8.3+$ above & $0.41 \pm 0.01 \ddagger$ & $0.52 \pm 0.09_{+}^{+}$ \\
\hline 2 & $5.0-10.5$ & $0.46 \pm 0.18$ & $0.54 \pm 0.06$ \\
\hline 3 & $3.0-6.0$ & $1.74 \pm 0.62$ & $1.52 \pm 0.48$ \\
\hline 4 & $2.0-3.5$ & $8.09 \pm 1.61$ & $8.86 \pm 0.99$ \\
\hline 5 & $1.0-2.0$ & $42.54 \pm 4.86$ & $35.27 \pm 3.66$ \\
\hline 6 & Up to 1.0 & $\underline{46.71} \pm 6.07$ & $53.34 \pm 3.62$ \\
\hline Total & & 99.95 & 100.05 \\
\hline
\end{tabular}
in the Animal Exposure Chamber

* From Andersen (11).

$\ddagger$ Mean of four individual determinations. 


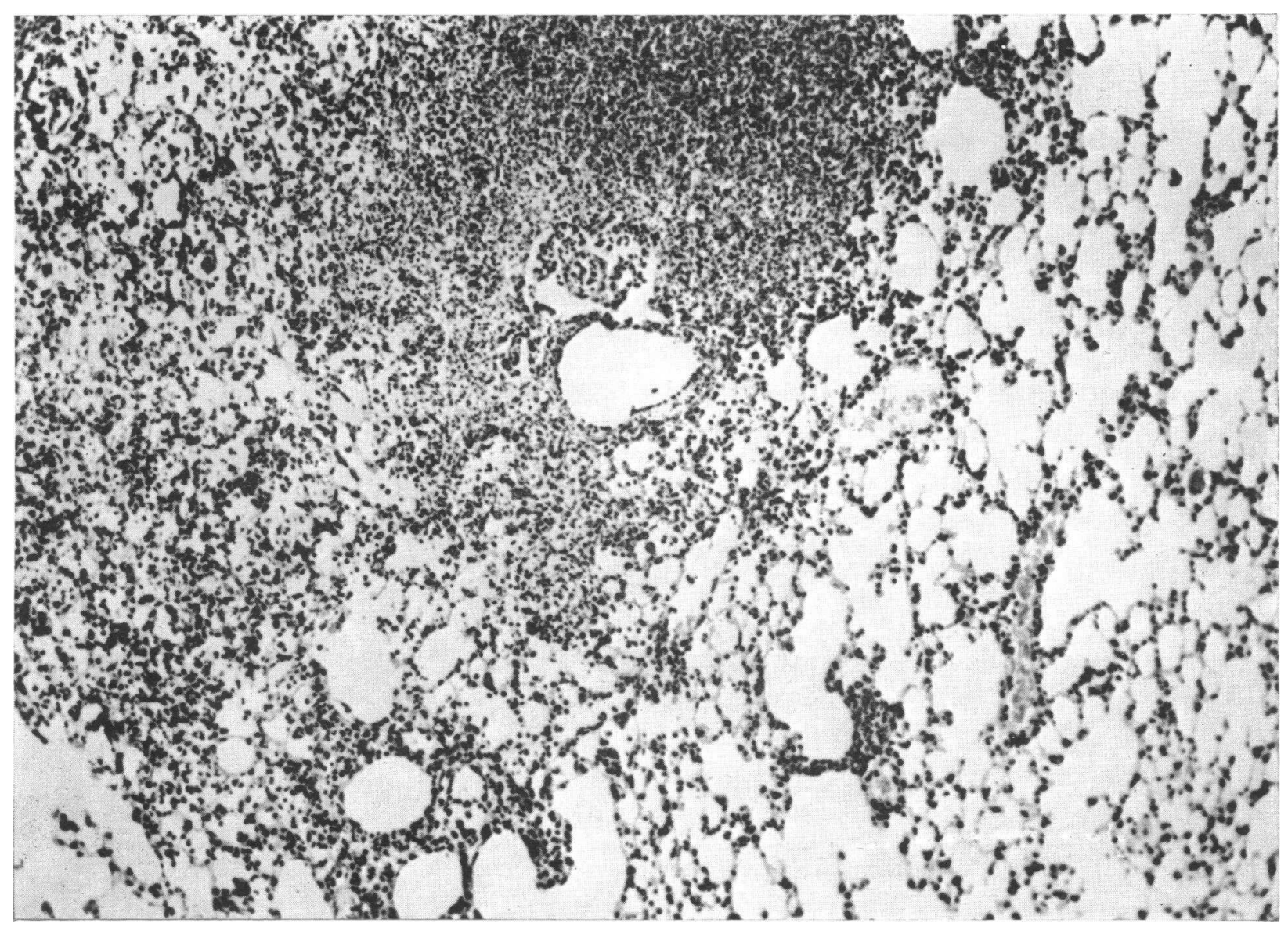

FIGURE 1 Photomicrograph of a section of lung from a mouse sacrificed 7 days after aerosol exposure to $10^{4}$ TCID $_{50}$ of Sendai virus. A dense area of solid consolidation (center) is bordered by an area of interstitial pneumonitis (left) and an area of seemingly normal lung tissue (right). Stained with hematoxylin and eosin, $\times 300$.

This method calculates bactericidal activity of the lung as a function independent of physical transport out of the lung (8). The per cent bacteria remaining in the $4,24,48$, and 72 -hr animals was normalized to the 0 -hr sacrifices, whose mean per cent bacteria remaining was assigned a value of $100 \%$.

Calculation of physical transport activity. Physical transport of ${ }^{32} \mathrm{P}$-labeled staphylococci from the lungs was determined by following the decline in radiotracer activity. The ${ }^{32} \mathrm{P}$ counts are expressed as the percentage of the mean radiotracer counts obtained from the 0 -hr sacrifices. As ${ }^{32} \mathrm{P}$ has a relatively short half-life $\left(\mathrm{t} \frac{1}{2}=14.2\right.$ days $)$, all samples from each experiment were assayed on the same day. This calculation provides a quantitative measurement of tracer excretion independent of the bactericidal activity of the lung and includes the excretion of both viable and nonviable organisms.

Histology. Histologic studies on the lungs of test animals were not possible, the entire lung being used for quantitation. Separate groups of mice were used for study of the pulmonary histology. The lungs of these mice were fixed in $10 \%$ formalin, sectioned at $6 \mu$ and stained with hematoxylin and eosin.
Statistical determinations. The data was analyzed by determining the arithmetic means, standard deviation (SD), and standard errors (SE). Comparisons were made according to the Student $t$ test (16).

\section{RESULTS}

Aerosol apparatus. The aerosol apparatus used in this study was extremely efficient in infecting large numbers of mice with reproducible doses of Sendai virus and ${ }^{32} \mathrm{P}$-labeled $S$. aureus. The particle size distribution of the bacterial aerosol is indicated in Table II. Over $97 \%$ of the infectious droplets and radiotracer recovered were in particles $<3.5 \mu$ in diameter. Maximum viral and bacterial concentrations in the exposure chamber were achieved after $3 \mathrm{~min}$ and remained constant until nebulization was discontinued. When samples of nebulizer fluid, sampler fluid, and lung homogenates were assayed, a linear increase was observed in the number of staphylococci in the chamber air (reflected by the sampler assay) and in the lungs in 
response to increasing concentrations of bacteria in the nebulizer. In each experiment, all mice received approximately $5 \times 10^{5}$ colony-forming units of staphylococci. None of the animals died of the viral infection and only $3 \%$ succumbed to the dual infection by $72 \mathrm{hr}$.

Pulmonary changes. On gross inspection, all virusinfected animals had visible consolidation on the surfaces of the lung 7 days after Sendai virus infection. Within the same lung, these pulmonary changes ranged from partial to essentially complete consolidation involving parts or the whole of one or more lobes. This diffuse involvement was also reflected in the histologic sections. Microscopically, the pathologic changes ranged from areas of seemingly uninvolved lung tissue to areas of interstitial pneumonitis and dense pneumonic consolidation (Fig. 1) usually confined to the region of terminal bronchioles. The process involved not less than an estimated $10 \%$ nor greater than $50 \%$ of the entire lung.
Bronchial involvement was slightly more extensive, varying between an estimated 30 and $80 \%$ of the bronchial surface area present in each section. The bronchial abnormalities consisted of intense peribronchial cuffing with inflammatory cells and epithelial cell desquamation (Fig. 2). Ciliated epithelial cells, goblet cells, and bronchial mucus gland cells were destroyed. The bronchial lumina were partially or completely occluded by cellular debris (Fig. 3). The bronchial basal layer remained intact. Beneath the basal layer, the basement membrane was swollen, congested, and diffusely infiltrated with predominantly mononuclear cells, the majority appearing to be large lymphocytes. The alveolar walls and alveoli were frequently infiltrated with an extension of peribronchial infiltrate (Fig. 2). These bronchial abnormalities were prevalent in areas of the lung with normal appearing alveoli, as well as in areas with pneumonic consolidation. In some instances, affected bronchi were immediately adjacent to morpho-

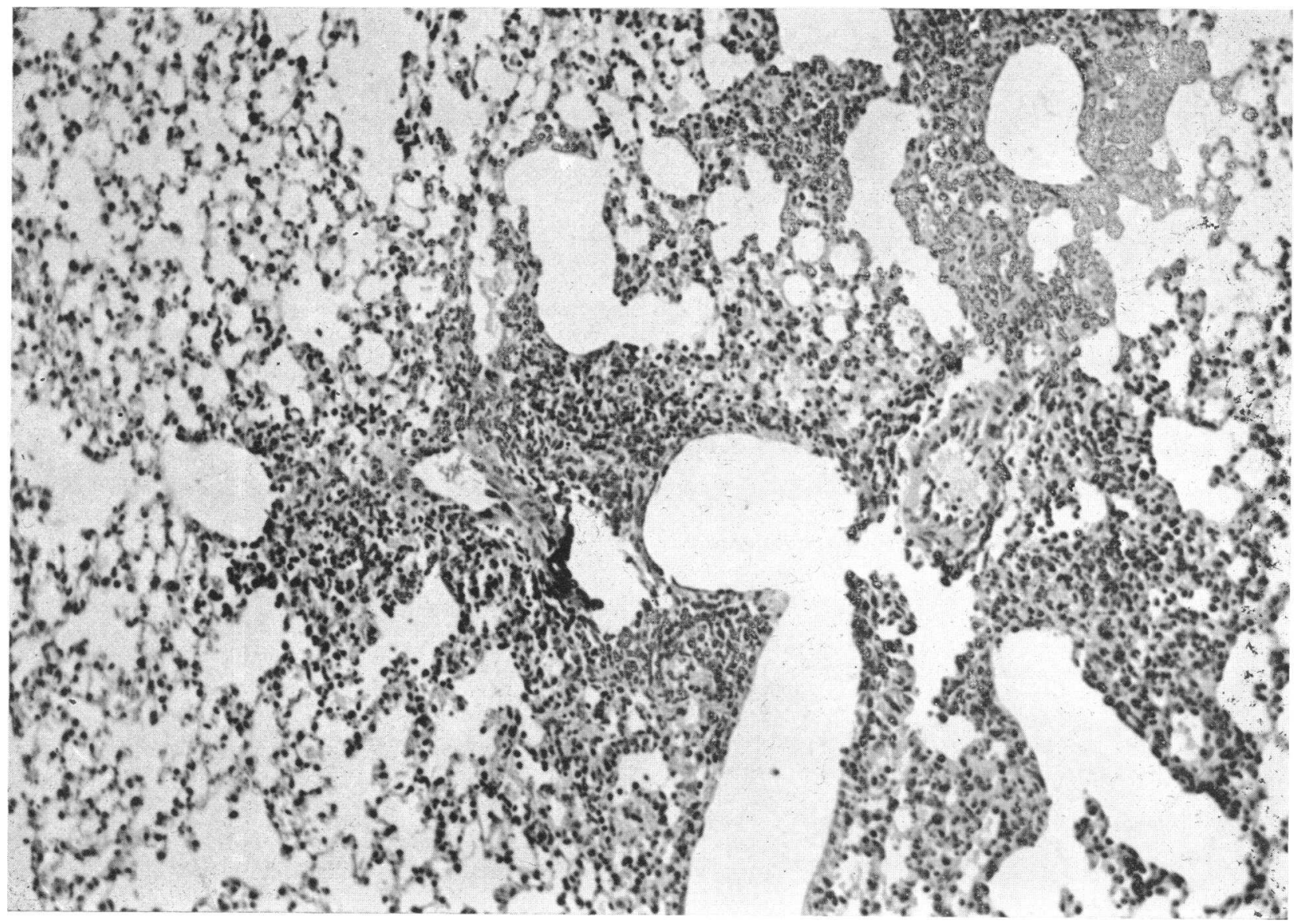

FIGURE 2 Section of mouse lung showing bronchi with completely desquamated epithelium. Bronchial walls are profusely infiltrated with mononuclear cells. Note the extension of the peribronchial infiltrate into the adjacent lung. Stained with hematoxylin and eosin, $\times 250$. 


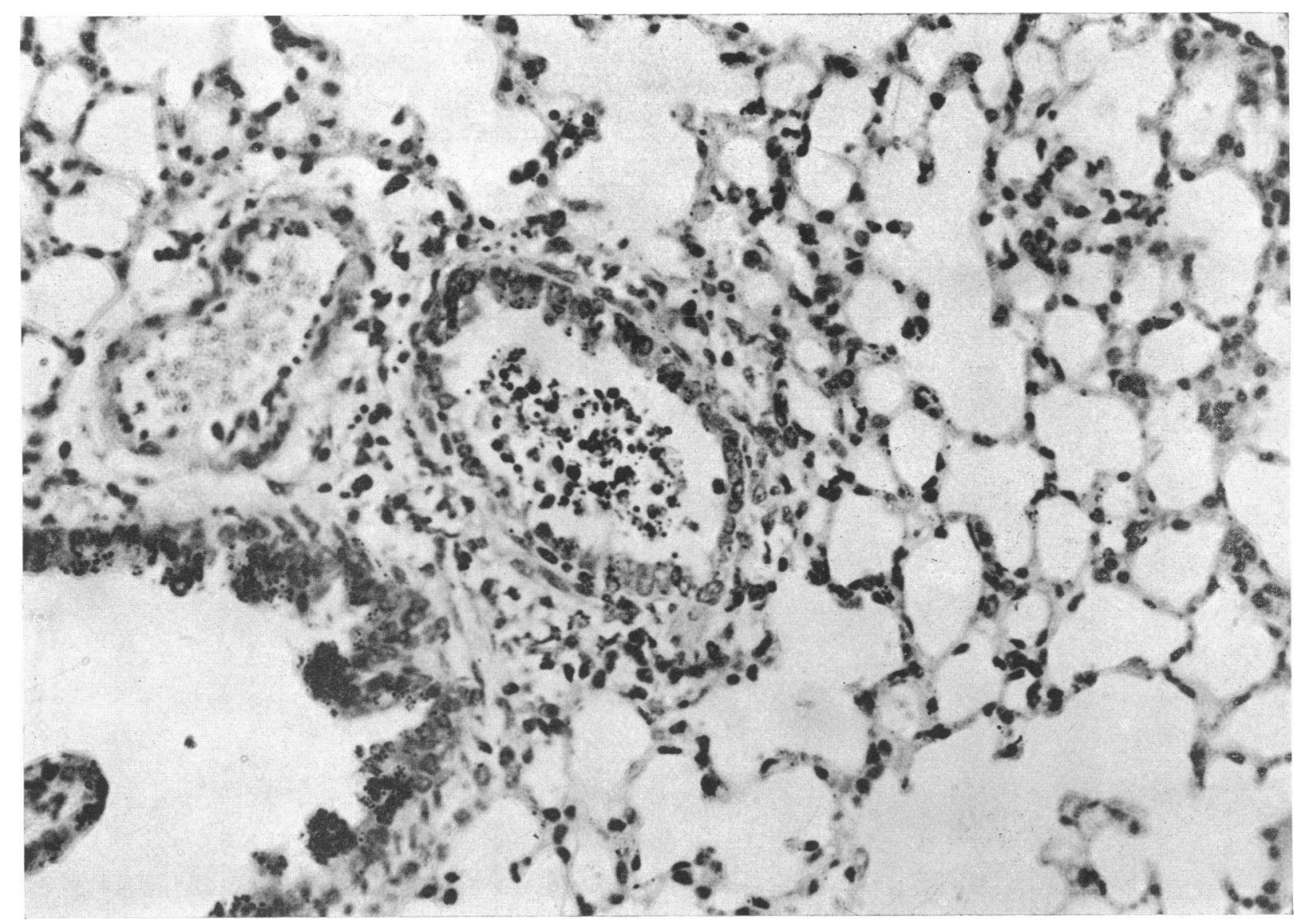

FIGURE 3 Section of mouse lung showing partial occlusion of the bronchi by inflammatory cells 7 days after Sendai virus infection. Note degenerative appearance in the bronchial epithelial cells and the absence of consolidation in the adjacent lung. Stained with hematoxylin and eosin, $\times 500$.

logically normal-appearing air passages. Lungs of all Sendai virus-infected animals possessed these gross and microscopic pathologic changes; however, there was considerable variation in the abnormalities among animals in any one group.

Bacterial deposition. Table III contains detailed data demonstrating bacterial and ${ }^{52} \mathrm{P}$ deposition in the lungs of noninfected and Sendai virus-infected animals. Immediately after aerosol challenge with ${ }^{32} \mathrm{P}$-labeled $S$. aureus, $228 \times 10^{3}$ viable staphylococci and $1736 \mathrm{cpm}$ of ${ }^{32} \mathrm{P}$ activity were recovered from noninfected as compared with $224 \times 10^{3}$ organisms and $1949 \mathrm{cpm}$ from the Sendai virus-infected animals. The difference between the number of staphylococci and radiotracer recovered at $0 \mathrm{hr}$ between control and Sendai virusinfected animals in this illustrative example, as in all other experiments, was not significant.

Bacterial inactivation. Table IV contains detailed data from one illustrative example of the four aerosol
TABLE III

Representative Single Experiment of Intrapulmonary Deposition of ${ }^{32} P$-Labeled Staphylococcus aureus in Noninfected and Sendai Virus-Infected Mouse Lungs

\begin{tabular}{cccccc}
\hline & \multicolumn{2}{c}{ Viable Staphylococci } & & \multicolumn{2}{c}{${ }^{32} \mathrm{P}$ cpm } \\
\cline { 2 - 3 } \cline { 5 - 6 } Animal & Noninfected & Infected & & Noninfected & Infected \\
\hline & \multicolumn{2}{c}{$\times 10^{3}$} & & & \\
1 & 300 & 474 & & 1954 & 3778 \\
2 & 232 & 168 & & 1686 & 1242 \\
3 & 377 & 270 & & 2472 & 2560 \\
4 & 180 & 195 & 1291 & 1497 \\
5 & 202 & 167 & 1384 & 1879 \\
6 & 165 & 350 & 1809 & 3211 \\
7 & 182 & 110 & & 1467 & 1136 \\
8 & 245 & 161 & & 1947 & 1358 \\
9 & 175 & 108 & 1617 & 882 \\
Mean & $228 \pm 23$ & $222 \pm 40$ & $1736 \pm 120$ & $1949 \pm 336$ \\
\hline
\end{tabular}




\section{TABLE IV}

Representative Single Experiment of Intrapulmonary Killing and Mechanical Clearance of ${ }^{32} P$-Labeled Staphylococcus aureus in Individual Mouse Lungs at Various Times after Exposure to Staphylococcal Aerosol

\begin{tabular}{|c|c|c|c|c|c|}
\hline \multirow[b]{3}{*}{$\begin{array}{l}\text { Time after } \\
\text { exposure }\end{array}$} & \multirow[b]{3}{*}{ Animal } & \multicolumn{2}{|c|}{ Bactericidal Activity } & \multicolumn{2}{|c|}{ Transport } \\
\hline & & \multicolumn{2}{|c|}{ Bacteria remaining* } & \multicolumn{2}{|c|}{$32 \mathrm{P}$ remaining* } \\
\hline & & $\begin{array}{c}\text { Non- } \\
\text { infected } \\
\mathbf{A}\end{array}$ & $\begin{array}{c}\text { Virus } \\
\text { infected } \\
\text { B }\end{array}$ & $\begin{array}{c}\text { Non- } \\
\text { infected } \\
\text { C }\end{array}$ & $\begin{array}{c}\text { Virus } \\
\text { infected } \\
\text { D }\end{array}$ \\
\hline & & \multicolumn{2}{|c|}{$\%$} & \multicolumn{2}{|c|}{$\%$} \\
\hline \multirow[t]{8}{*}{$4 \mathrm{Hr}$} & 1 & 27.0 & 63.8 & 129.5 & 74.1 \\
\hline & 2 & 14.3 & $58.4_{+}^{+}$ & 117.1 & 106.1 \\
\hline & 3 & 23.8 & $68.5^{\circ}$ & 95.5 & 75.9 \\
\hline & 4 & 16.9 & 88.3 & 96.5 & 78.2 \\
\hline & 5 & 78.9 & 59.5 & 85.3 & 129.0 \\
\hline & 6 & 15.6 & 44.5 & 91.8 & 83.5 \\
\hline & 7 & 8.5 & 73.1 & 79.6 & 75.3 \\
\hline & 8 & 15.9 & 42.9 & 88.8 & 140.8 \\
\hline Mean $\pm \mathrm{sE}$ & & $25.1 \pm 7.9$ & $62.4 \pm 5.3$ & $98.0 \pm 5.9$ & $95.4 \pm 9.4$ \\
\hline \multirow[t]{8}{*}{$24 \mathrm{Hr}$} & 1 & 1.1 & 48.5 & 83.6 & 63.1 \\
\hline & 2 & 0.3 & 292.8 & 56.9 & 76.3 \\
\hline & 3 & 0.9 & 89.5 & 54.2 & 75.4 \\
\hline & 4 & 0.4 & $289.8 \ddagger$ & 78.2 & 63.2 \\
\hline & 5 & 10.0 & 4.7 & 55.7 & 71.6 \\
\hline & 6 & 0.9 & 61.0 & 30.9 & 31.6 \\
\hline & 7 & 4.2 & 575.9 & 79.6 & 24.2 \\
\hline & 8 & 0.7 & 761.4 & 60.8 & 63.0 \\
\hline Mean $\pm \mathrm{SE}$ & & $2.3 \pm 1.1$ & $265.4 \pm 97.4$ & $62.5 \pm 6.2$ & $58.6 \pm 6.9$ \\
\hline \multirow[t]{8}{*}{$48 \mathrm{Hr}$} & 1 & 0.1 & 548.3 & 53.4 & 44.6 \\
\hline & 2 & 0.1 & 295.7 & 46.1 & 21.1 \\
\hline & 3 & 0.1 & 22.8 & 31.6 & 68.9 \\
\hline & 4 & 0.1 & 10.5 & 38.3 & 86.7 \\
\hline & 5 & 0.1 & $123.6 \ddagger$ & 38.0 & 75.9 \\
\hline & 6 & 0.1 & $45.7 \ddagger$ & 32.7 & 20.0 \\
\hline & 7 & 0.1 & 371.9 & 42.6 & 46.7 \\
\hline & 8 & 4.0 & 40.6 & 33.6 & 62.1 \\
\hline Mean \pm SE & & $0.6 \pm 0.5$ & $182.4 \pm 70.7$ & $39.5 \pm 2.6$ & $53.3 \pm 8.7$ \\
\hline \multirow[t]{8}{*}{$72 \mathrm{Hr}$} & 1 & 0.1 & 1.9 & 27.6 & 34.9 \\
\hline & 2 & 0.1 & 6.9 & 22.6 & 77.0 \\
\hline & 3 & 0.8 & 1724.5 & 21.4 & 21.7 \\
\hline & 4 & 1.3 & 2683.1 & 26.1 & 24.5 \\
\hline & 5 & 0.1 & 9.8 & 35.8 & 50.3 \\
\hline & 6 & 2.8 & 3.1 & 31.6 & 63.4 \\
\hline & 7 & 0.0 & 1283.8 & 34.0 & 30.7 \\
\hline & 8 & 0.2 & 91.6 & 18.7 & 37.2 \\
\hline Mean \pm SE & & $0.7 \pm 0.3$ & $725.6 \pm 368.8$ & $27.2 \pm 2.2$ & $42.5 \pm 6.9$ \\
\hline
\end{tabular}

* Per cent of initial bacteria and ${ }^{32} \mathrm{P}$ radiotracer counts recovered from eight noninfected and eight virus-infected animals sacrificed immediately after bacterial challenge.

‡Indicates mice from which Gram-negative bacteria were recovered.

experiments performed to determine the rate of inactivation and physical removal of ${ }^{32} \mathrm{P}$-labeled $S$. aureus in individual Sendai virus-infected and noninfected mouse lungs. The data from this single experiment reflect the variability observed throughout the entire study and illustrates points which would escape detection when the mean of each experiment is computed (Table $\mathrm{V}$ ), or the mean of the entire study is presented (Figs. 4 and 5 ).

Examination of pulmonary bactericidal values of in- 
dividual murine lungs (Table IV, columns $A$ and $B$ ) $4 \mathrm{hr}$ after bacterial challenge reveals a rapid decline of viable staphylococci to $25.1 \pm 7.9 \%$ in the noninfected animals as compared with $62.4 \pm 5.3 \%$ in those previously infected with Sendai virus. In the latter group, bacterial inactivation was consistently delayed in each animal ( $P<0.001$ for mean of the two groups). After $4 \mathrm{hr}$, whereas values for noninfected animals steadily declined to $2.3,0.6$, and $0.7 \%$ at 24,48 , and $72 \mathrm{hr}$, three patterns of pulmonary bactericidal activity were observed in the Sendai virus mice: $(a)$ delayed bacterial inactivation, (b) relative stasis of the bacterial population at 4-hr levels, and $(c)$ bacterial prolifera- tion. These three patterns reflect the variations in pulmonary bactericidal capacity among animals in response to Sendai virus infection.

The data in Table $\mathrm{V}$ were observed by pooling individual bactericidal and ${ }^{*} \mathrm{P}$ removal values in each experiment. The mean figure represents the mean results from six to nine individual animals. The variation among the means from run-to-run is, in general, smaller than animal variation and is quantified in the grand mean for each category illustrated in Figs. 4 and 5. $4 \mathrm{hr}$ after staphylococcal challenge, bactericidal values differed significantly between virus-infected and noninfected animals $(P<0.01)$. Thereafter, the degree of

TABLE V

Intrapulmonary Killing and Mechanical Clearance of ${ }^{22} P$-Labeled Staphylococcus aureus by Lungs of Mice at Various Times after Exposure to Staphylococcal Aerosol

\begin{tabular}{|c|c|c|c|c|c|}
\hline \multirow[b]{3}{*}{ Time after exposure } & \multirow[b]{3}{*}{ Experiment } & \multirow{2}{*}{\multicolumn{2}{|c|}{$\frac{\text { Bacteria remaining } \neq}{\text { Mean } \pm \mathrm{SE}}$}} & \multirow{2}{*}{\multicolumn{2}{|c|}{$\frac{2 \mathrm{P} \text { remaining } \ddagger}{\text { Mean } \pm \mathrm{SE}}$}} \\
\hline & & & & & \\
\hline & & $\begin{array}{c}\text { Non- } \\
\text { infected } \\
\text { A }\end{array}$ & $\begin{array}{c}\text { Virus } \\
\text { infected } \\
\text { B }\end{array}$ & $\begin{array}{c}\text { Non- } \\
\text { infected } \\
\text { C }\end{array}$ & $\begin{array}{c}\text { Virus } \\
\text { infected } \\
\text { D }\end{array}$ \\
\hline & & \multicolumn{2}{|c|}{$\%$} & \multicolumn{2}{|c|}{$\%$} \\
\hline Grand mean $\pm \mathrm{SE} \S$ & $\begin{array}{ll}1 & (6)^{*} \\
2 & (8) \\
3 & (9) \\
4\end{array}$ & $\begin{array}{r}8.4 \pm 1.2 \\
25.1 \pm 7.9 \\
27.8 \pm 3.1 \\
\text { ND } \\
20.4 \pm 3.4 \\
\quad(F\end{array}$ & $\begin{array}{c}45.1 \pm 10.9 \\
62.3 \pm 5.2 \\
72.1 \pm 5.0 \\
\text { ND } \\
59.8 \pm 3.6 \\
<0.001)\end{array}$ & $\begin{array}{c}86.0 \pm 4.0 \\
98.0 \pm 5.9 \\
100.9 \pm 5.0 \\
\text { ND } \\
94.9 \pm 3.2 \\
(P>0.2\end{array}$ & $\begin{array}{l}73.3 \pm 12.1 \\
95.3 \pm 9.4 \\
86.6 \pm 18.3 \\
\text { ND } \\
85.1 \pm 8.6 \\
<0.3)\end{array}$ \\
\hline Grand mean $\pm S E$ & $\begin{array}{ll}1 & (6) \\
2 & (8) \\
3 & (9) \\
4 & (8)\end{array}$ & $\begin{array}{l}2.5 \pm 1.0 \\
2.3 \pm 1.1 \\
1.2 \pm 0.7 \\
3.5 \pm 2.9 \\
2.4 \pm 0.9\end{array}$ & $\begin{array}{c}575.0 \pm 229.1 \\
265.5 \pm 97.4 \\
788.5 \pm 469.0 \\
1149.5 \pm 1019.6 \\
694.6 \pm 292.3\end{array}$ & $\begin{array}{l}59.1 \pm 1.7 \\
62.5 \pm 6.1 \\
57.8 \pm 4.6 \\
59.2 \pm 3.2 \\
59.6 \pm 2.2 \\
\quad(P>0.2\end{array}$ & $\begin{array}{l}31.9 \pm 4.9 \\
58.5 \pm 6.9 \\
44.8 \pm 14.8 \\
71.6 \pm 9.1 \\
51.7 \pm 5.7 \\
<0.3)\end{array}$ \\
\hline Grand mean $\pm \mathrm{SE}$ & $\begin{array}{l}1 \\
2(8) \\
3(8) \\
4(7)\end{array}$ & $\begin{array}{l}\text { ND } \\
0.5 \pm 0.4 \\
0.1 \pm 0.0 \\
0.4 \pm 0.2 \\
0.3 \pm 0.2\end{array}$ & \begin{tabular}{l}
\multicolumn{1}{c}{ ND } \\
$182.4 \pm 70.6$ \\
$160.5 \pm 102.0$ \\
$353.6 \pm 83.9$ \\
$232.2 \pm 51.1$
\end{tabular} & $\begin{array}{c}\text { ND } \\
39.5 \pm 2.6 \\
46.1 \pm 2.7 \\
35.6 \pm 2.7 \\
40.4 \pm 1.8 \\
\quad(P>0.02\end{array}$ & $\begin{array}{l}\quad \text { ND } \\
53.3 \pm 8.6 \\
50.9 \pm 7.6 \\
52.2 \pm 11.2 \\
52.1 \pm 5.0 \\
<0.03)\end{array}$ \\
\hline Grand mean $\pm \mathrm{SE}$ & $\begin{array}{l}1 \\
2(8) \\
3(8) \\
4(6)\end{array}$ & $\begin{array}{c}\text { ND } \\
0.6 \pm 0.3 \\
0.1 \pm 0.0 \\
0.1 \pm 0.0 \\
0.3 \pm 0.1\end{array}$ & $\begin{array}{c}\text { ND } \\
725.6 \pm 368.8 \\
25.4 \pm 13.5 \\
403.4 \pm 258.0 \\
384.8 \pm 168.5\end{array}$ & $\begin{array}{c}\text { ND } \\
27.2 \pm 2.1 \\
34.5 \pm 1.9 \\
24.9 \pm 1.4 \\
28.9 \pm 1.3 \\
\quad(P>0.01\end{array}$ & $\begin{array}{l}\quad \text { ND } \\
42.5 \pm 6.9 \\
31.0 \pm 3.1 \\
48.6 \pm 8.7 \\
40.7 \pm 3.8 \\
<0.02)\end{array}$ \\
\hline
\end{tabular}

$\mathrm{ND}=$ not done.

* Number in brackets is the number of animals in each noninfected and virus-infected groups involved in the computation.

¥ Per cent of initial bacteria and ${ }^{32} \mathrm{P}$ radiotracer counts recovered from noninfected and virus-infected animals sacrificed immediately after bacterial challenge.

$\S$ Determined by calculating the mean and SE of the total individual values. 


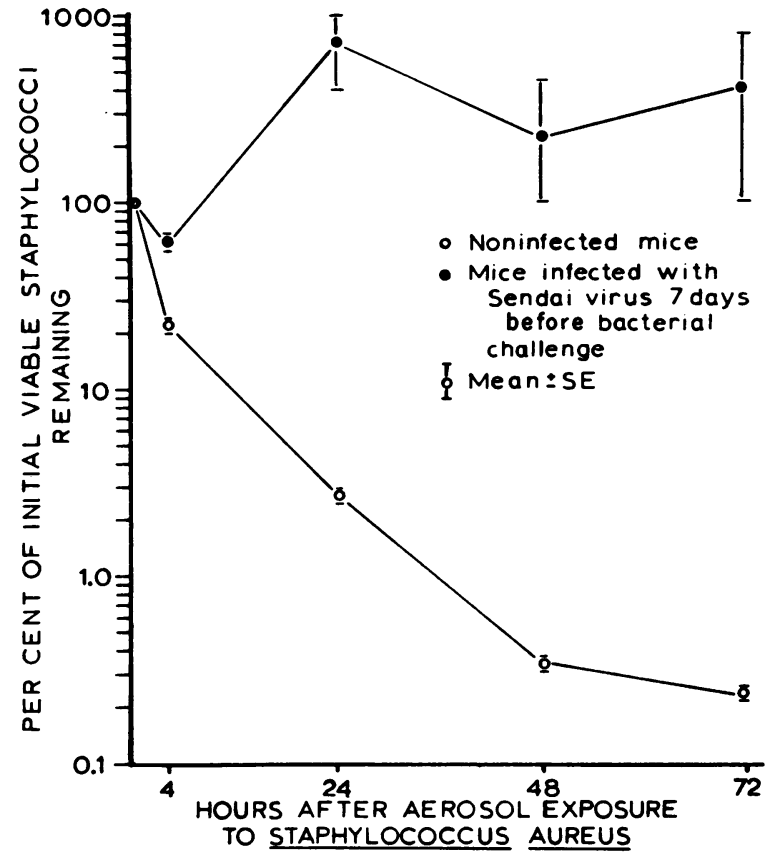

FIgURE 4 Comparison of pulmonary bactericidal activity in noninfected and Sendai virus-infected mice. Each point represents the mean of $22-31$ mice.

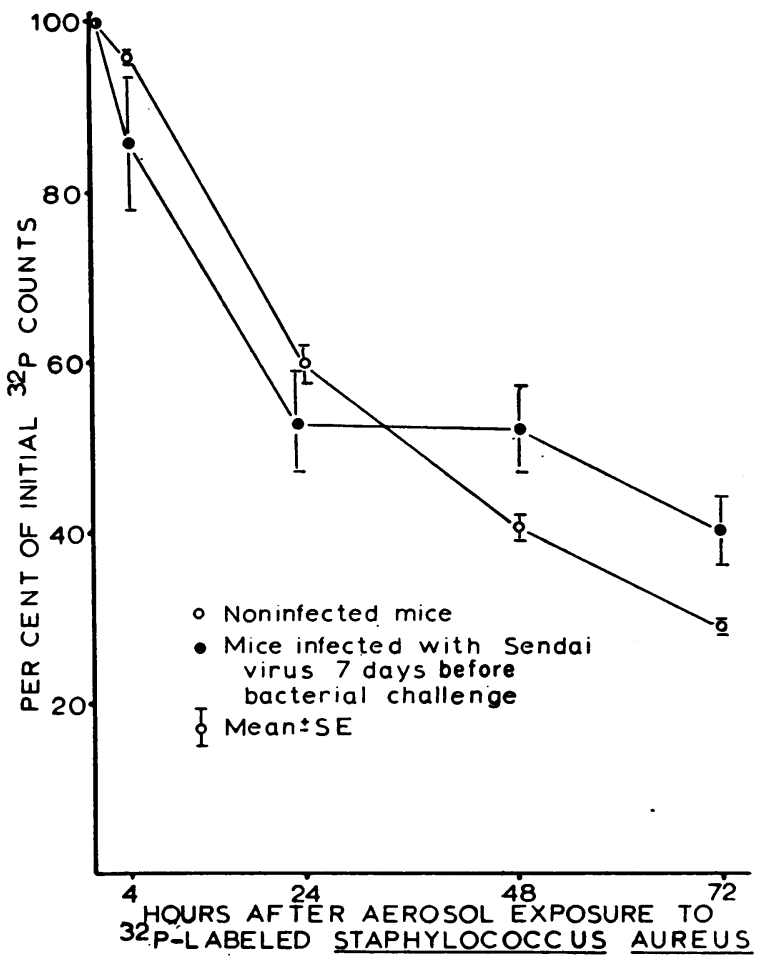

Figure 5 Comparison of transport of ${ }^{22} \mathrm{P}$-labeled $S$. aureus from the lungs of noninfected and Sendai virus-infected mice. Each point represents the mean of 22-31 mice. significance of the differences in bactericidal activity between the mean values could not be calculated by the $t$ test, due to extensive bacterial proliferation in a portion of the animals which consistently caused the variance to overlap zero. However, examination of Fig. 4, which illustrates graphically the mean pulmonary bactericidal values for all the animals used in this study, will confirm the vast differences in pulmonary bactericidal capacity between virus-infected and noninfected animals.

A Gram-negative bacillus, assumed to be of endogenous origin, was seen in approximately $10 \%$ of the lung homogenates of the virus-infected mice. The organism could be clearly distinguished from $S$. aureus on the culture plates by colonial morphology. It appeared at random and was not correlated with the extent of suppression of bactericidal activity or with staphylococcal proliferation. In some instances, this Gram-negative bacillus was recovered in greater numbers than were staphylococci.

Physical removal. Tables IV and V also compare the decline in pulmonary radiophosphorus at all time intervals for each of the four experiments. Declines in ${ }^{32} \mathrm{P}$ radiotracer in infected lungs were similar to those in noninfected lungs at 4 and $24 \mathrm{hr}$ (Fig. 5). However, at 48 and $72 \mathrm{hr}$, there was a small but significant difference in the retention of tracer in the control vs. infected animals (Table V, columns $\mathrm{C}$ and $\mathrm{D}$ ). Infected lungs retained 52.1 and $40.7 \%$ of the initial radioactivity as compared with 40.4 and $28.9 \%$ in the noninfected lungs.

\section{DISCUSSION}

The inhibiting effect of Sendai virus infection on murine pulmonary antibacterial activity is maximal when viral exposure precedes bacterial challenge by $6-7$ days (6). This impairment of bactericidal activity is not associated in time with virus proliferation but rather with the peried of rapid decline in pulmonary virus titers and with the appearance of serum antibody. Pulmonary histologic changes, however, marked by epithelial cell destruction, peribronchial inflammatory cell infiltration, and tissue necrosis were prominent during the period of peak clearance suppression.

The findings that virus infection inhibits bactericidal activity in the lung, permits multiplication of a challenge bacterial organism, and does not affect early transport despite visible destruction of the respiratory epithelium raise the following questions about: (a) the significance of the bronchial lesions for subsequent bacterial infection in the lung, $(b)$ the mechanism of virus inhibition of the bactericidal activity in the lung, and $(c)$ other possible mechanisms allowing pulmonary bacterial proliferation. 
Ciliary action removes foreign particles from the tracheobronchial tree (17). It is commonly held that viral lesions of the respiratory epithelium impair transport of bacteria via the mucociliary apparatus and facilitate direct invasion of the bacteria into the lung parenchyma. These studies show that transport of bacterial particles out of the lung in the early postexposure period was normal in Sendai virus-infected animals. Early transport is reported to depend heavily on the mucociliary mechanism of the tracheobronchial tree (18). Therefore, the normal transport of tracer-labeled particles found in the virus-infected animals with the epithelial lesions suggests three possible explanations: $(a)$ transport in the tracheobronchial tree does not depend on the integrity of the mucociliary epithelium, $(b)$ transport involves pathways other than the apparatus of the tracheobronchial tree or $(c)$ deposition in diseased animals was shifted away from damaged and blocked bronchi so that a greater proportion of the inoculum was deposited on, or distal to, uninfected and normally functioning respiratory epithelium. The first explanation would present a radical departure from traditional concepts of tracheobronchial function in particle elimination and may, therefore, be open to question. However, no data exists on tracheobronchial transport rates in the absence of ciliated epithelium so that this alternative remains a possibility. Secondly, alternative transport pathways, such as peribronchial and perivascular lymphatics, may compensate for defects in the mucociliary transport apparatus. Thirdly, alterations of deposition patterns with a shift toward noninvolved lung could occur because of reduced ventilation in infected areas caused by bronchial occlusion, consolidation, atelectasis, and changes in lung compliance. If the bacterial challenge was shunted to functionally normal pulmonary areas then the integrity of the bronchial epithelium in the areas, with lesions would be of little consequence to the early physical removal of particles since relatively few particles would have been deposited there. Recent data from this laboratory ${ }^{2}$ support this last mechanism. Finally, the delays in transport seen at 48 and $72 \mathrm{hr}$ might be due to inhibition of one or more of the complex alveolar removal mechanisms (3).

The findings of Green and Kass (4) concerning the disproportionate decrease in radioactivity and viable staphylococci from the lungs of mice exposed to ${ }^{32} \mathrm{P}-\mathrm{la}-$ beled $S$. aureus focused on the importance of intrapulmonary bactericidal mechanisms in contrast to transport as the main defense mechanism in the lungs against bacterial infection. They found that $4 \mathrm{hr}$ after exposure to aerosolized tracer-labeled bacteria, the radiolabel persisted at approximately postdeposition levels while cul-

\footnotetext{
${ }^{2}$ Jakab, G. J., and G. M. Green. In preparation.
}

turable bacteria rapidly decreased. By immunofluorescent methods, the inhaled bacteria were found to be localized in the alveolar spaces and within alveolar macrophages. These results showed that the rapid decline in viable staphylococci was due not to mechanical removal but rather to the microbicidal functions of the alveolar macrophage.

The quantitative bacteriological and radiotracer assays performed in these experiments indicate that Sendai virus infection inhibits the bactericidal activity of the mouse lung. The proliferation of endogenous bacterial species in some of these animals further demonstrates the effect of the virus infection and adds evidence for this conclusion.

Green (2) and, later, Klein, Green, Tilles, Kass, and Finland (5), working respectively with influenza and reovirus, demonstrated that the antibacterial ability of the mouse lung was reduced after virus infection and attributed this change to an effect on the alveolar macrophage system. The inhibitory effect on the antibacterial activity of phagocytic cells by virus infection has been described earlier $(7,19)$. These in vitro studies suggest a direct antiphagocytic action of the virus on the leukocytes; however, the nature of the in vivo effects of virus infection on alveolar macrophages remain to be conclusively demonstrated.

Possible explanations for impairment of bactericidal activity in virus-infected lungs would include $(a)$ a uniform phagocytic defect throughout the entire lung; $(b)$ a phagocytic defect limited to local areas (i.e., consolidated) where localized bacterial multiplication outweighed normal bactericidal activity in the rest of the lung; (c) total absence of phagocytic activity in local consolidated areas with impaired microbicidal activity in the remaining lung; and $(d)$ the overloading of macrophages in the nonconsolidated areas of the lung due to preferential shunting of particles away from consolidated areas.

It has been suggested that the inception of bacterial pneumonia is dependent on the virus-induced inflammatory lesion. In previous studies (20) (also confirmed herein), virus-induced pneumonic lesions were consistently observed in those mice with pulmonary microbicidal defects. Quantitative differences in bactericidal activity may exist in these areas with lesions when contrasted to portions of the same lung without lesions. Consequently, questions must be raised about local effects in pneumonic areas which may override normally functioning bactericidal activity in the rest of the lung. Alternatively, the macrophages in virus-infected lungs may be overloaded with staphylococci due to the shunting of the bacterial challenge to the nonconsolidated areas. Recent observations ${ }^{2}$ indicate that in fact, consolidation does result in the shunting of most of the inhaled 
particles away from the consolidated areas. However, consolidation involved at most $50 \%$ of the lungs. If all bacteria were shunted to nonconsolidated areas, the number of bacteria per macrophage (assuming all macrophages were involved) would increase only twofold. Inspection of the data of Table III shows that the variation in the number of bacteria deposited among virusinfected animals is greater than twofold so that the chance burden of macrophages with particles is greater than possible by shunting; yet the depression in bactericidal activity in the virus-infected animals at $4 \mathrm{hr}$ was consistent (Table IV). Furthermore, the over-all particle burden is light- $50-100,000$ organisms are deposited in the lungs containing many times that number of macrophages. These considerations suggest that particle overload is an unlikely explanation for phagocyte failure.

The data of this paper demonstrate clearly that host resistance to bacterial infection in the murine lung during Sendai virus infection is impaired through a defect in bactericidal mechanisms and not, as commonly supposed, by a transport defect in the mucociliary stream or alveolar transport system. Although this model comments rather directly on the pathogenic relationship between influenza and staphylococcal pneumonia, the viral-induced defect may aggravate other disease processes which involve phagocytic mechanisms.

\section{ACKNOWLEDGMENTS}

The authors thank Mrs. Joan Green, Misses Jeanne Lisbon and Linda Pfeiffer for their technical assistance.

This work was aided by Grant A1 08900-02, National Institutes of Health, U. S. Public Health Service.

\section{REFERENCES}

1. Loosli, C. G. 1968. Synergism between respiratory viruses and bacteria. Yale J. Biol. Med. 40: 522.

2. Green, G. M. 1966. Patterns of bacterial clearance in murine influenza. Antimicrobial Agents and Chemotherapy-1965. G. L. Hobby, editor. American Society for Microbiology 1966, Ann Arbor, Mich. 26.

3. Green, G. M. 1968. Pulmonary clearance of infectious agents. Annu. Rev. Med. $19: 315$.
4. Green, G. M., and E. H. Kass. 1963. The role of the alveolar macrophage in the clearance of bacteria from the lung. J. Exp. Med. 119: 167.

5. Klein, J. O., G. M. Green, J. G. Tilles, E. H. Kass, and M. Finland. 1969. Effect of intranasal reovirus infection on antibacterial activity of mouse lung. $J$. Infect. Dis. 119: 43.

6. Jakab, G. J., and E. C. Dick. 1970. Synergistic effect in dual respiratory infection of mice with Sendai virus and Pasturella pneumotropica by aerosol. Bacteriol. Proc. 116.

7. Sawyer, W. D. 1969. Interaction of influenza virus with leukocytes and its effect on phagocytosis. J. Infect. Dis. 119: 541 .

8. Green, G. M., and E. Goldstein. 1966. A method for quantitating intrapulmonary bacterial inactivation by individual animals. J. Lab. Clin. Med. 68: 669.

9. Henderson, D. W. 1952. An apparatus for the study of airborne infection. J. Hyg. 50: 53

10. British Standards Institution Document No. 68/13484 Ammended, June, 1968. Sodium Chloride Particulate Test for Respirator. Filters.

11. Andersen, A. A. 1958. New sampler for the collection, sizing, and enumeration of viable airborne particles. J. Bacteriol. $76: 471$.

12. Public Health Service Publication No. 686. April 1959. Sampling Microbiological Aerosols.

13. Guyton, A. C. 1947. Measurement of the respiratory volumes of laboratory animals. Am. J. Physiol. 150: 70.

14. Jakab, G. J. 1967. Experimental Sendai virus infection in mice. Master of Science Thesis. University of Wisconsin, Madison, Wis.

15. Jakab, G. J. 1970. Synergistic effect in dual respiratory infection of mice with Sendai virus and Pasturella pneumotropica by aerosol. Doctorate Thesis. University of W-isconsin, Madison, Wis.

16. Schor, S. S. 1968. Fundamentals of Biostatistics. G. P. Putnam's Sons, New York. 145.

17. Kilburn, K. H. 1967. Cilia and mucus transport as determinants of the response of lung to air pollutants. Arch. Environ. Health. 14: 77.

18. Morrow, P. E. 1970. Experimental studies of inhaled materials. Arch. Intern. Med. 126: 466.

19. Merchant, D. J., and H. R. Morgan. 1950. Inhibition of phagocytic action of leukocytes by mumps and influenza viruses. Proc. Soc. Exp. Biol. Med. 74: 651.

20. Harford, C. G., V. Leidler, and M. Hara. 1949. The effect of the lesion due to influenza virus on the resistance of mice to inhaled pneumococci. J. Exp. Med. 89: 53 . 